\title{
KONSEP DESAIN ALAT UJI KINERJA SERVO-VALVE DESIGN CONCEPT OF TESTING MACHINE OF SERVO-VALVE PERFORMANCES
}

\author{
Harris Zenal \\ Balai Besar Teknologi Kekuatan Struktur - BPPT \\ Kawasan PUSPIPTEK Gd.220 Serpong, Tangerang 15314 \\ e-mail : harriszenal@yahoo.com
}

Tanggal masuk naskah : 04/03/2014; Tanggal revisi: 01/04/2014; Tanggal persetujuan cetak : 30/05/2014

\begin{abstract}
Abstrak
Konsep desain alat uji kinerja servo-valve terdiri atas konsep desain mekanis dan konsep desain elektronik. Konsep desain mekanis meliputi hydraulic power pack yang dilengkapi pengaman dan monitor tekanan dan flowrate, servo-valve dan base-plate-nya, flow-meter untuk monitor flow-rate di port $A$ dan $B$. Konsep desain elektronik meliputi pembangkit signal input kepada servo-valve, signal output dari flow-meter $A$ dan $B$, akuisisi signal output flowmeter, hardware dan software komputer. Grafik Signal Input (m-Ampere) versus Signal Output (LPM) dapat membantu analisa untuk mengetahui kinerja servovalve antara lain keakurasian, mendeteksi kerusakan servo-valve untuk selanjutnya dapat diambil tindakan pemeliharaan dan perbaikan.
\end{abstract}

Kata Kunci : servo-valve, input signal, output flow rate ,alat uji kinerja.

\begin{abstract}
Design concept of performance test equipment for servo-valve consists of mechanical and electronic systems. The mechanical parts includes a hydraulic power pack equipped with safety and monitoring of pressure and flow-rate, servo-valve and its base-plate, flow-meter for monitoring flow-rate in $A$ and $B$ ports. The electronic system parts includes a signal generator to the servovalve, output signal from flow meter $A$ and $B$ ports, acquisition for signal output flow-meter, hardware and software computer. The form of graph Input Signal ( $m$ Ampere) versus Output Signal (LPM) can help analyze to determine servo-valve performance, that are accuracy and detect damage which can be taken for further maintenance and repair.
\end{abstract}

Keywords : servo-valve, signal input, flow rate output, performance test machine.

\section{PENDAHULUAN.}

Untuk menjaga mutu dan daya saing suatu produk perlu dilakukan pengujian kekuatan struktur terhadap produk tersebut dengan mengikuti standar tertentu. Khususnya hasil produk konstruksi seperti wahana transportasi (pesawat terbang, kapal laut, alat transportasi darat, dan lainlain), pengujian kekuatan struktur biasanya dilakukan pada tahap awal produksi berupa prototype (sampel produk). Dari pengujian prototype di laboratotium dapat diketahui lebih awal kekuatan dan mutu hasil produksi terhadap beban operasi dan kekuatan umur operasi, sehingga dapat membantu modifikasi dan pengembangan produk yang lebih baik pada tahap produk serial.

Pengujian kekuatan struktur pada suatu konstruksi prototype pada dasarnya adalah memberikan beban operasi pada konstruksi prototype tersebut. Beban yang akan diberikan 
terlebih dahulu diteliti posisi titik beban pada prototype dan besarannya. Pengujian dilakukan di laboratorium dengan menggunakan peralatan yang mampu menyerupai beban operasi di lapangan. Beban yang diberikan kepada prototype dapat berupa beban statis maupun beban dinamis. Aplikasi beban statis pada benda uji bertujuan untuk mengetahui ketahanan maksimum, sedangkan aplikasi beban dinamis pada prototype bertujuan untuk mengetahui ketahanan pemakaian (umur pakai). Hasil dari kegiatan pengujian kekuatan struktur ini digunakan untuk mengetahui batasan toleransi yang telah ditentukan oleh standar baik nasional maupun internasional, juga dapat digunakan untuk bahan evaluasi untuk pengembangan yang lebih baik hasil produk lebih lanjut.

Untuk dapat membangkitkan beban uji yang akan diaplikasi kepada benda uji diperlukan seperangkat peralatan yang sesuai kebutuhan. Biasanya pem bangkit beban berkapasitas besar dibangkitkan oleh peralatan berbasis hidrolik. Peralatan pembangkit beban berbasis hidrolik diintegrasikan sedemikian rupa sehingga dapat diguna kan untuk kegiatan pengujian dan pembebanan.

Peralatan pengujian berbasis hidrolik meliputi hydraulic power pack sebagai sumber utama tenaga hidrolik, pipa dan slang hidrolik, blok distribusi, sistem pengerak aktuator, kontrol beban (servo-valve, servo-controller), sensor umpan balik, dan sistem pengaman baik hidrolik, elektronik, maupun software.

Semua sistem hidrolik dan sistem elektronik dikoordinasi oleh seperangkat komputer yang didalamnya terdapat aplikasi perangkat lunak dengan spesifikasi khusus untuk mengontrol pengujian dan pembebanan.

Pada sistem hidrolik, salah satu peralatan penting yang digunakan untuk mengontrol pengujian adalah servovalve. Gambar 1 memperlihatkan sebuah servo-valve produk dari MOOG. Servo-valve ini berfungsi mengontrol aliran fluida yang berasal dari hydraulic power pack melewati servo-valve menuju hidrolik aktuator. Servo-valve akan mengontrol pergerakan hidrolik aktuator naik atau turun dan juga akan mengontrol besar dan frekuensi gerakan. Kontrol aliran di dalam servovalve dikendalikan oleh suatu instrumen elektronik dengan input signal dari luar.

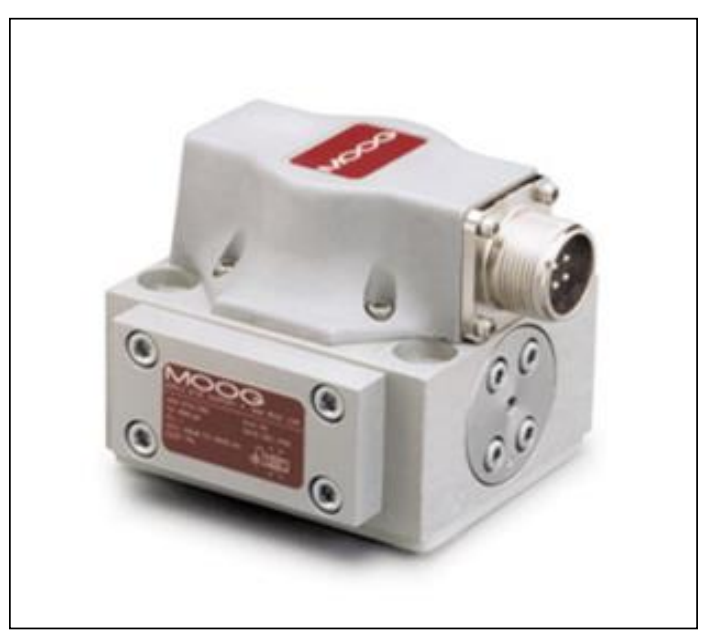

Gambar 1: Servo-valve

Servo-valve memiliki pintu masuk $\mathrm{P}$, pintu keluar $\mathrm{R}$, $\mathrm{A}$ dan $\mathrm{B}$. Fluida bertekanan tertentu masuk mengalir melalui pintu masuk $P$. Pintu keluar $R$ berfungsi sebagai pintu keluar fluida jika pintu $A / B$ belum terbuka maka fluida kembali ke tangki. Jika pintu keluar A digunakan mengalirkan fluida, maka pintu B secara otomatis terhubung ke pintu keluar R. Begitu sebaliknya jika pintu keluar B digunakan mengalirkan fluida. Pada servo-valve terdapat instrumen elektronik yang mengatur mekanisme tersebut diatas. Terjadi kolerasi antara signal input yang diberikan dengan besar/kecilnya volume fluida yang keluar pada pintu output $A / B$.

Kinerja servo-valve secara periodik perlu diketahui keakurasiannya agar pengujian secara keseluruhan berjalan dengan benar dan akurat. Untuk itu diperlukan suatu alat uji kinerja servovalve yang dapat membantu mengetahui dan menganalisa kinerja servovalve. Uji kinerja servo-valve pada prinsipnya adalah membandingkan command input dengan respon output. Command input berupa signal elektrik dengan besaran tertentu, sedangkan respon output adalah volume fluida 
(flow-rate) yang mengalir melalui pintu output $A$ atau melalui pintu output B. Kinerja servo-valve dapat diilustrasikan pada Gambar 2 dibawah ini.

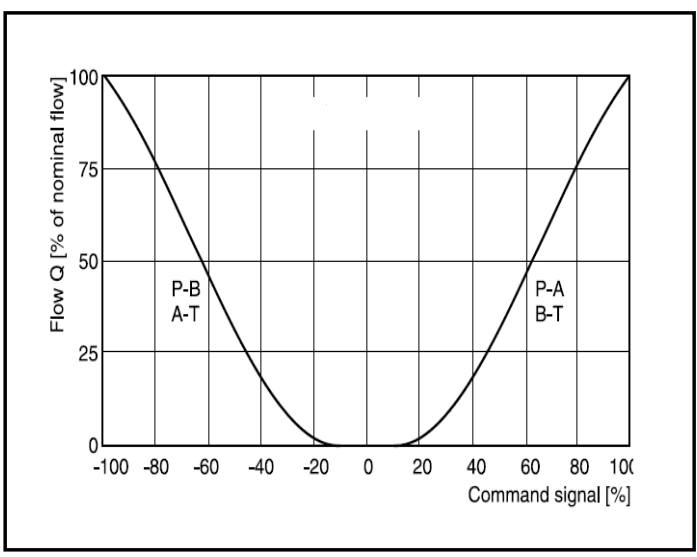

Gambar 2 : Grafik Command Signal vs Flow Rate

Persamaan Command Input dalam satuan mAmpere menjadi Respon Output dalam satuan LPM (Liter per Menit) ditunjukan dengan persamaan sebagai berikut:

$$
\frac{C_{i}}{\operatorname{Nom}_{c}}=\frac{R_{i}}{\text { Nom }_{r}}
$$

$C_{i} \quad$ : Command Input (mAmpere) ke i $\mathrm{Nom}_{c}$ : Nominal Command Input (mAmpere)

$R_{i} \quad$ : Respon Output (LPM) ke i

Nom $_{r}$ : Nominal Respon Output (LPM)

Pada penelitian ini peralatan yang digunakan sebagian besar menggunakan peralatan dengan spesifikasi yang dimiliki oleh B2TKS (Balai Besar Teknologi Kekuatan Struktur), untuk perancangan alat uji kinerja servo-valve dengan tipe lain perlu dilakukan beberapa penyesuaian. Diharapkan kegiatan penelitian dan perancangan ini dapat diwujudkan lebih lanjut menjadi prototype alat uji kinerja servo-valve dengan mengintegrasikan peralatan yang telah tersedia di B2TKS serta dengan mengadakan bahan dan komponen yang belum tersedia sehingga kegiatan pengembangan alat uji kinerja servo-valve yang nyata dapat dilakukan dengan baik. Diharapkan juga dampaknya akan meningkatkan mutu pengujian.
Dari sisi ketersediaan sumber daya manusia, pengalaman yang telah dilakukan yakni menggunakan mesin uji servo-valve yang ada walaupun beberapa tahun ini mesin dalam keadaan rusak, serta melakukan reparasi mesin uji servo-valve, merekayasa sistem kontrol servo dan sistem data akuisisi berbasis komputer sangat membantu untuk dapat mengembangkan dan mewujudkan perekayasaan alat uji kinerja servovalve ini dengan baik.

\section{BAHAN DAN METODA.}

Pada kegiatan perancangan alat uji kinerja servo-valve ini bahan dan peralatan yang digunakan meliputi hydraulic power pack yang memiliki fasilitas kontrol tekanan dan debit, jaringan pemipaan baik yang fixed pipe maupun flexible hose, mesin uji servovalve yang pada saat dilakukan penelitian ini dalam status keadaan rusak, servo-valve dengan merek tertentu dengan berbagai macam tipe.

Bahan literatur juga dipelajari untuk mendalami sistem hidrolik, sistem kerja servo-valve, sistem kontrol hidrolik, sistem data akuisisi dan sistem pemeliharaan.

Metoda penelitian dan perekayasa-an dilakukan dengan tahapan yakni melakukan penelitian dan pemahaman terhadap mekanisme proses sistem kontrol servo-valve yang ada, juga melakukan studi literatur yang berkaitan dengan servo-valve. Selanjutnya dilaku-kan perancangan dan uji konsep.

Dari konsep disain pada tahap ini dapat dilanjutkan dengan merumuskan mekanisme dan sistem kerja secara keseluruhan dilakukan persiapan dan pengadaan barang yang dibutuhkan, setelah semua selesai, uji coba unjuk kerja sistem dilakukan, pengembangan dan perbaikan hasil rekayasa perlu terus dilanjutkan secara terus menerus untuk mendapatkan alat uji kinerja servo-valve yang optimal. 


\section{HASIL DAN PEMBAHASAN.}

Hasil rancangan alat uji kinerja servo-valve terdiri dari rancangan sistem alat uji kinerja servo-valve secara keseluruhan, rancangan sistem hidrolik, rancangan input signal, rancangan output signal, dan rancangan pengolahan data dan reporting.

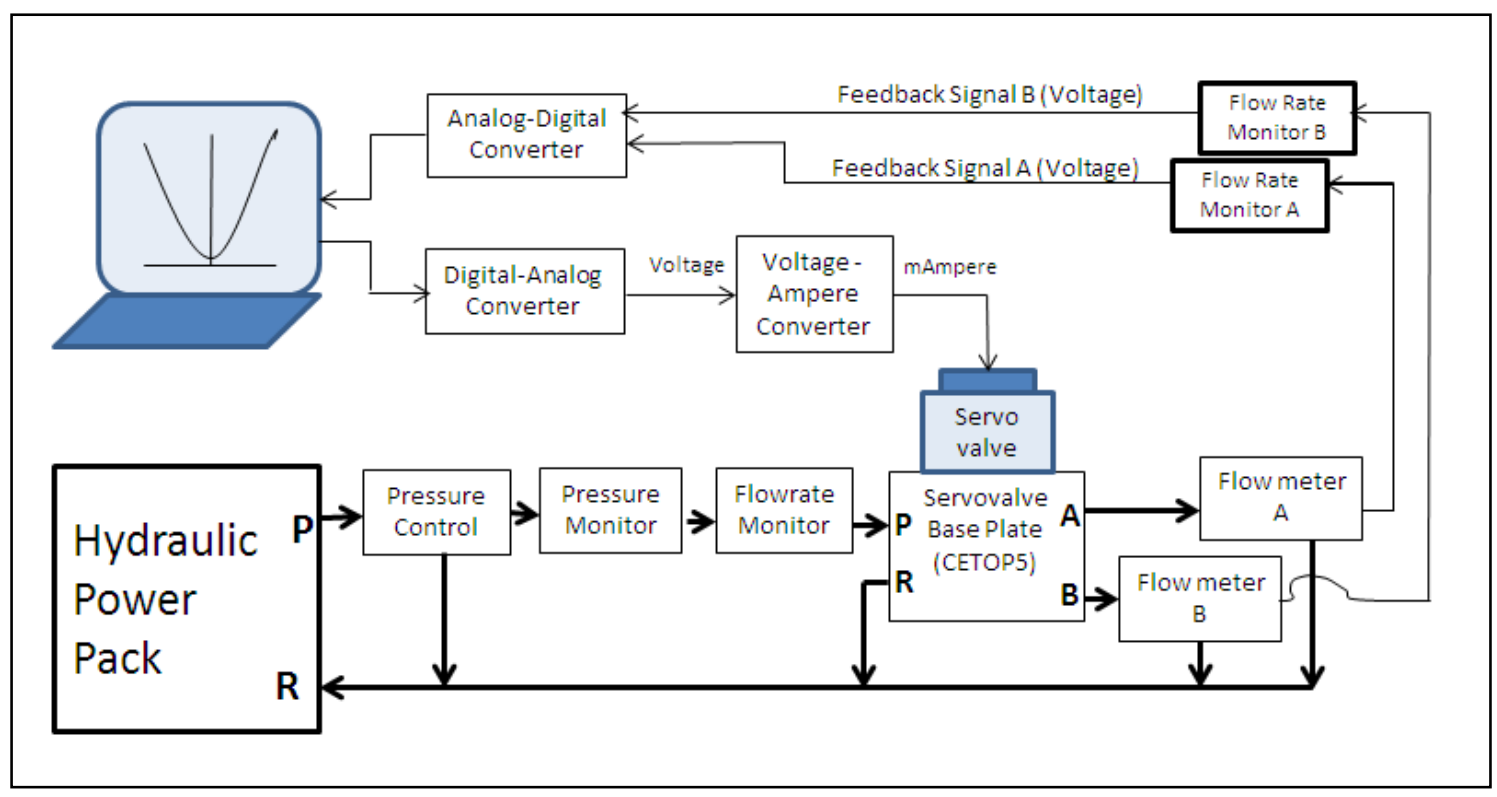

Gambar 3 : Diagram Sistem Alat Uji Kinerja Servo-valve

\subsection{Rancangan Sistem Alat Uji Kinerja Servo-valve.}

Rancangan sistem alat uji kinerja servo-valve dapat dilihat pada Gambar 3. Hydraulic power pack mengalirkan fluida bertekanan kepada servo-valve, yang dilengkapi dengan kontrol dan monitor tekanan (bar), juga flow-meter untuk memonitor flow-rate (LPM). Fluida yang di-supply oleh hydraulic power pack mengalir ke base-plate servo-valve yang dibuat khusus dengan jaringan lubang sesuai standar CETOP5. Servovalve diinstal diatas base-plate servovalve. Aliran fluida pada servo-valve dikendalikan oleh input signal mili Ampere, apakah ke port A atau port B, serta berapa besar volume yang akan dialirkan.

Input signal dibangkitkan oleh komputer dan dikirim kepada servovalve melalui peralatanan Digital to Analog Converter (DAC) dan Voltage to Ampere Converter (VAC).
Pada port A dan B dipasang flowmeter untuk mengetahui flow-rate yang terjadi. Flow-meter juga dilengkapi dengan Flow-rate-monitoring yang disamping men-display-kan besaran flow-rate juga mengeluarkan signal analog untuk selanjutnya dikirim ke komputer melalui Analog to Digital Conveter (ADC).

\subsection{Rancangan Sistem Hidrolik.}

Rancangan sistem hidrolik meliputi hydraulic power pack sebagai sumber daya utama yang mengalirkan fluida kepada servo-valve, yang dilengkapi dengan sistem kontrol pengaman dan monitoring beberapa parameter seperti tekanan, flow-rate, temperature, filter, dan lain-lain. Spesifikasi hydraulic power pack pada penelitian ini adalah milik B2TKS, maksimum supply fluida 350 LPM, tekanan maksimum 310 bar (adjustable), tekanan yang biasa digunakan adalah 280 bar. 
Output fluida dari hydraulic power pack mengalir ke servo-valve base-plate melalui selang hidrolik. Servo-valve base plate yang digunakan mengikuti aturan lubang standar CETOP5.

Servo-valve diinstal di atas servovalve base-palte dengan posisi tertentu. Servo-valve yang digunakan adalah produk MOOG, dengan spesifikasi tekanan maksimum 350 bar, two stage servo-valve, input signal 15/40/60/200 mAmpere, flow 5/10/19/38/63/65 LPM.

Koneksi antara hydraulic power pack dan servo-valve base-plate adalah sebagai berikut (1) P hydraulic power pack dihubungkan ke pintu masuk $P$ servo-valve base-plate; (2) return $R$ hydraulic power pack dihubungkan ke pintu keluar $\mathrm{R}$ servo-valve base-plate; (3) pintu keluar A servo-valve base-plate dihubungkan ke flow-meter $\mathrm{A}$; (4) pintu keluar B servo-valve base-plate dihubungkan ke flow-meter B. Gambar 3 menjelaskan secara diagram rancangan sistem hidrolik tersebut.

Flow-meter yang akan dipergunakan tentunya harus dapat mengalirkan volume fluida minimal sama dengan output dari servo-valve yakni sekitar 65 LPM. Dari penelusuran katalog produsen flow-meter, maka produk merek STAUFF type SGF cocok untuk rancangan ini yang mempunyai spesifikasi teknis (1) flow range 0.002 250 LPM; (2) tekanan maksimum untuk cast iron housing 315 bar, sedangkan untuk stainless steel housing 450 bar; (3) Sebagai base-plate flow-meter digunakan tipe SGFM dengan drat input-output $1 / 2$ inchi; (4) dapat dihubungkan kepada flow-rate display type STD1 yang dapat menampilkan secara digital besaran flow-rate yang terjadi, disamping itu juga flow-rate display ini dilengkapi monitor flow-rate signal dalam besaran analog 0-10 Volt, sehingga dapat di akuisisi oleh komputer untuk direkam dan diolah lebih lanjut.

Aliran fluida output dari flow-meter A maupun flow-meter B dikembalikan kepada return $\mathrm{R}$ Hydraulic Power Pack.

\subsection{Rancangan Input Signal.}

Input signal merupakan signal elektrik yang diinputkan kepada servovalve untuk mengendalikan aliran fluida yang akan keluar dari servo-valve pada pintu output $A / B$. Besar kecilnya volume fluida yang mengalir ke pintu output $A$ atau pintu output $B$ berbanding lurus dengan besar kecilnya signal input yang diberikan. Spesifikasi servo-valve yang digunakan pada penelitian ini adalah input signal mili-Ampere yang mengedalikan besar kecilnya aliran fluida yang akan keluar melalui pintu output $A / B$.

Rancangan input signal hingga servo-valve dapat dilihat pada Gambar 5 di bawah ini. Input signal dibangkitkan berawal dari perangkat komputer yang mengirim signal digital kepada DAC. Signal digital dikonversi oleh DAC menjadi signal analog dengan range besaran +/- 10 Volt. Ouput signal analog selanjutnya dihubungkan kepada VAC untuk dikonversi menjadi signal analog dengan range besaran +/- 60 mili Ampere. Selanjutnya signal analog besaran mili-Ampere dikirimkan kepada servo-valve sehingga akan mengakibatkan pengendalian besar kecilnya keluaran fluida pada pintu output $A / B$.

Gambar 4 memperlihatkan DAC yang digunakan yang memiliki spesifikasi (1) type multi function USB4716 module; (2) 2 channels analog output; (3) 16 channels analog input; (4) 16-bit resolusion; (5) sampling-rate up to $200 \mathrm{kS} / \mathrm{s}$.

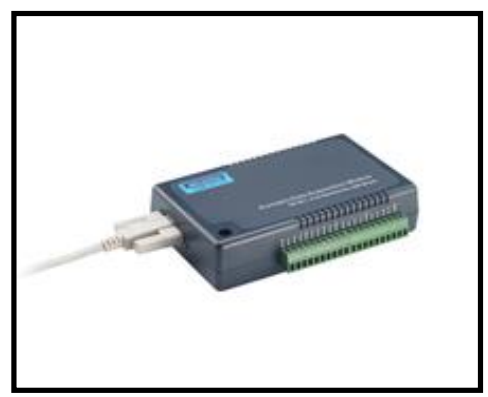

Gambar 4 : Advantech USB-4716 module 
Gambar 6 memperlihatkan VAC yang memiliki spesifikasi (1) type VC2100 two axis Voltage to Current Converter; (2) 2 channels VCC; (3) Full scale output current +/- $10 \mathrm{~mA}$ to $+/-100$ $\mathrm{mA}$ in $10 \mathrm{~mA}$ step; (4) Input voltage range +/- $10 \mathrm{~V}$; (5) Frequency $1.4 \mathrm{kHz}$.

Gambar 5. Konversi Signal Input hingga ke Servo-valve

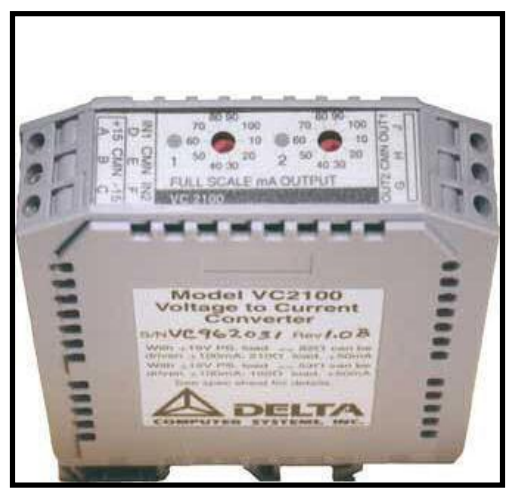

Gambar 6 : VAC Delta Computer System VC2100 module

Servo-valve adalah suatu valve yang berfungsi mengontrol aliran fluida yang masuk dan keluar servo-valve. Servo-valve memiliki pintu masuk $P$ dan pintu keluar R, A dan B. Pada servovalve terdapat instrumen elektronik yang mengendalikan arah dan volume aliran. Input signal elektrik mengakibatkan terjadi pengendalian aliran fluida. Terjadi hubungan kolerasi antara signal input dan volume fluida yang keluar pada port $A$ atau port B. Specifikasi servo-valve yang digunakan pada penelitian ini adalah (1) MOOG Servo-valve; (2) tekanan maksimum 350 bar, two stage servo-valve, input signal +/- 15/40/60/200 mAmpere, flow-rate 5/10/19/38/63/65 LPM.

Jika dihubungkan antara kebutuhan input signal servo-valve +/- $60 \mathrm{~mA}$ dan output mili Ampere VCC, maka pada
VCC dapat di set kepada +/- $60 \mathrm{~mA}$, yang mana voltage yang harus dikeluarkan oleh DAC adalah +/- $10 \mathrm{~V}$. Konversi dari signal input hingga servovalve seperti yang telah diilustrasikan pada Gambar 5.

\subsection{Rancangan Output Signal.}

Rancangan output signal dapat diilustrasikan seperti Gambar 7 dibawah ini. Diawali dengan penentuan flow-rate maksimum dari servo-valve contoh 65 LPM, maka dibutuhkan flow-meter untuk membaca flow-rate tersebut. Berdasarkan ketersediaan flow-meter produk stauff, dapat diambil type SGF1, maksimum flow-rate 80 LPM dan diintegrasikan dengan flow-rate- display STD1, 0-10 Volt analog output. Flowrate 80 LPM SGF1 akan dikonversi menjadi signal analog 0-10 Volt oleh STD1.

Signal output dari STD1 yaitu analog 0-10 Volt akan dibaca oleh USB4716 untuk dikonversi dari analog menjadi digital value. Spesifikasi USB4715 (1) 16 channels analog input; (2) 16-bit resolusion; (3) sampling rate up to $200 \mathrm{kS} / \mathrm{s}$.

Digital value hasil konversi USB4716 dibaca oleh komputer dan akan dilakukan proses perekaman data dan pengolahan data lebih lanjut. 


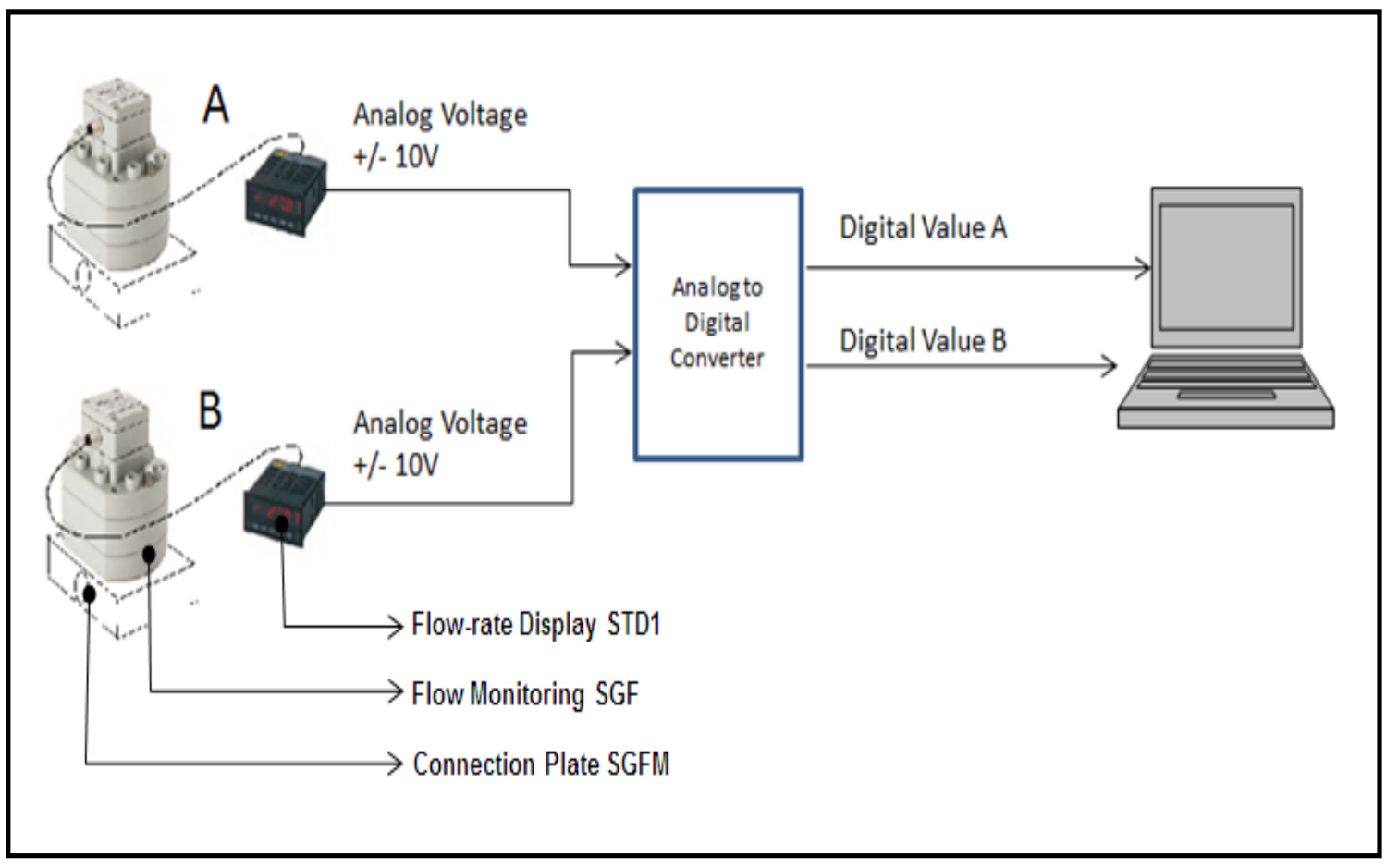

Gambar 7 : Konversi Signal output hingga ke Komputer.

Flow-meter A yang terintegrasi dengan flow-rate-display A mengeluarkan signal analog yang selanjutnya dihubungkan ke USB-4716 melalui pin 0 (digital value $A$ ), sedangkan flow-meter $B$ yang terintegrasi dengan flow-ratedisplay B mengeluarkan signal analog yang selanjutnya dihubungkan ke USB4716 melalui pin 1 (digital value $B$ ). Digital value A dan B selanjutnya akan direkam dan diproses lebih lanjut oleh komputer dan software yang telah dikembangkan.

\subsection{Rancangan Pengolahan Data dan Reporting.}

Rancangan pengolahan data dan reporting meliputi pengukuran dan perekaman data input command yang berasal dari digital value $\mathrm{C}$, dan data dari signal flow-meter A yang terintegrasi dengan flow-rate-display A yang mengeluarkan signal analog voltage A. Signal analog voltage $A$ dikonversi oleh ADC menjadi digital value A. Juga data dari signal flowmeter $\mathrm{B}$ yang terintegrasi dengan flow- rate-display $\mathrm{B}$ yang mengeluarkan signal analog voltage B. Signal analog voltage B dikonversi oleh ADC menjadi digital value $B$. Pada pengujian kinerja servo-valve secara statis akan dibuat laporan seperti terlihat pada Gambar 8 .

Metode perekaman dilakukan dalam dua bentuk pengujian yaitu pengujian statis dan pengujian dinamis. Pada pengujian statis, perekaman dilakukan step-by-step. Signal input dinaikkan bertahap setiap $10 \%$ nominal. Setiap step dilakukan perekaman data signal value $C$, signal analog $A$, dan signal analog $B$.

Sedangkan pada pengujian dinamis, perekaman dilakukan secara continue, yaitu iterasi signal value $\mathrm{C}$ yang bergerak dari 0 menuju $100 \%$ nominal dengan jedah waktu yang ditentukan. Setiap kali iterasi dilakukan maka dilakukan perekaman data signal value $\mathrm{C}$, signal analog $\mathrm{A}$, dan signal analog $\mathrm{B}$. 
Nominal : $+/-60$ mAmpere Nominal : 65 LPM

\begin{tabular}{rrrrrr}
\hline Step & $\%$ & $\begin{array}{r}\text { Input } \\
\text { (mAmpere) }\end{array}$ & $\begin{array}{r}\text { Respon A } \\
\text { (LPM) }\end{array}$ & $\begin{array}{r}\text { Respon B } \\
\text { (LPM) }\end{array}$ \\
\hline 1 & 0 & 0.00 & 0.00 & 0.00 \\
\hline 2 & 10 & 6.00 & 6.50 & 6.50 \\
\hline 3 & 20 & 12.00 & 13.00 & 13.00 \\
\hline 4 & 30 & 18.00 & 19.50 & 19.50 \\
\hline 5 & 40 & 24.00 & 26.00 & 26.00 \\
\hline 6 & 50 & 30.00 & 32.50 & 32.50 \\
\hline 7 & 60 & 36.00 & 39.00 & 39.00 \\
\hline 8 & 70 & 42.00 & 45.50 & 45.50 \\
\hline 9 & 80 & 48.00 & 52.00 & 52.00 \\
\hline 10 & 90 & 54.00 & 58.50 & 58.50 \\
\hline 11 & 100 & 60.00 & 65.00 & 65.00 \\
\hline 12 & 90 & 54.00 & 58.50 & 58.50 \\
\hline 13 & 80 & 48.00 & 52.00 & 52.00 \\
\hline 14 & 70 & 42.00 & 45.50 & 45.50 \\
\hline 15 & 60 & 36.00 & 39.00 & 39.00 \\
\hline 16 & 50 & 30.00 & 32.50 & 32.50 \\
\hline 17 & 40 & 24.00 & 26.00 & 26.00 \\
\hline 18 & 30 & 18.00 & 19.50 & 19.50 \\
\hline 19 & 20 & 12.00 & 13.00 & 13.00 \\
\hline 20 & 10 & 6.00 & 6.50 & 6.50 \\
\hline 21 & 0 & 0.00 & 0.00 & 0.00 \\
\hline
\end{tabular}

Gambar 8 : Contoh uji kinerja servo-valve secara statis

Untuk menentukan keakurasian kinerja servo-valve pada posisi step tertentu dapat dicari dengan persamaan:

$$
A_{i}=\frac{R_{i} / N_{f}}{C_{i} / N_{c}} 100 \%
$$

$$
\begin{array}{ll}
\mathrm{A}_{\mathrm{i}} & \text { : Akurasi ke } \mathrm{i}: \\
\mathrm{R}_{\mathrm{i}} & : \text { Respon ke i } \\
\mathrm{N}_{\mathrm{f}} & : \text { Nominal flow-meter } \\
\mathrm{C}_{\mathrm{i}} & : \text { Command Input ke i } \\
\mathrm{N}_{\mathrm{c}} & : \text { Nominal Command Input }
\end{array}
$$

Untuk menentukan nilai keakurasian kinerja servo-valve rata-rata dari semua step pengukuran dapat dicari dengan persamaan:

$$
A_{r}=\frac{\sum \frac{R_{i} / N_{f}}{C_{i} / N_{c}}}{n} 100 \%
$$

\footnotetext{
Ar : : Akurasi rata-rata:

$\mathrm{R}_{\mathrm{i}} \quad$ : Respon ke i

$\mathrm{N}_{\mathrm{f}} \quad$ : Nominal flow-meter

$\mathrm{C}_{\mathrm{i}} \quad$ : Command Input ke i

$\mathrm{N}_{\mathrm{c}} \quad$ : Nominal Command Input

n : banyak data
}

Untuk menentukan hubungan linear keakurasian kinerja servo-valve pada posisi semua step pengukuran dapat dicari dengan persamaan:

$$
\begin{gathered}
y=a+b x \\
a=\frac{\left(\sum y\right)\left(\sum x^{2}\right)-\left(\sum x\right)\left(\sum x y\right)}{n\left(\sum x^{2}\right)-\left(\sum x\right)^{2}} \\
b=\frac{n\left(\sum x y\right)-\left(\sum x\right)\left(\sum y\right)}{n\left(\sum x^{2}\right)-\left(\sum x\right)^{2}}
\end{gathered}
$$

Pada pengujian kinerja servovalve secara dinamis akan dibuat laporan seperti terlihat pada Gambar 9

Pengujian dilakukan dengan cara melakukan iterasi input signal dari 0 ke +60 mA, kemudian kembali dari +60 ke 0 , kemudian dari 0 ke -60 , kemudian kembali dari -60 ke 0 . Setiap kali dilakukan iterasi dengan step tertentu dilakukan perekaman data input value $C$, output value $A$, dan output value $B$. Maka selanjutnya diolah menjadi grafik seperti Gambar 9.

Command Input (mAmpere) vs Output Flow (LPM)

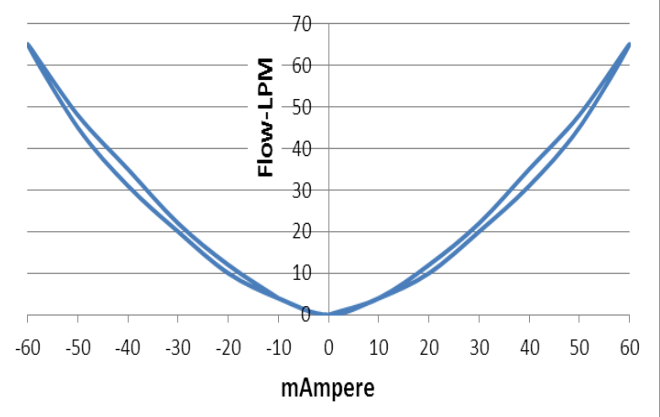

Gambar 9 :Comand Input (mAmpere) versus Output Flow (LPM)

\subsection{Kinerja Servo-valve}

Seperti dapat dilihat pada gambar 10, pada dasarnya kebutuhan alat uji kinerja servo-valve didasarkan pada kebutuhan informasi keakurasian antara input yang diberikan dengan respon output yang terjadi. 
Suatu servo-valve dari pabrik misalkan memiliki spesifikasi input signal +/- 60 mili Ampere dan output flow rate 65 LPM, serta keakurasiannya $100 \%$. Penjelasannya adalah jika di inputkan signal +60 mili Ampere maka output flow-rate yang terjadi seharusnya 65 LPM kearah port A, begitu juga jika di inputkan signal -60 mili Ampere maka output rate yang terjadi seharusnya 65 LPM kearah port $B$.

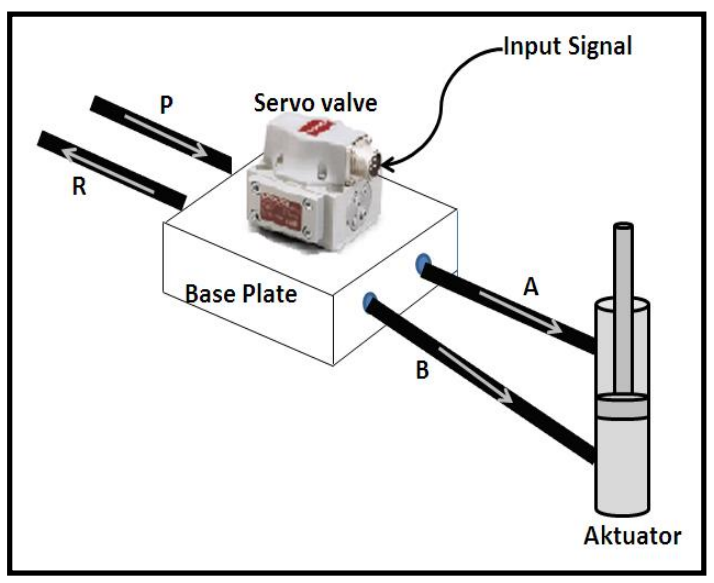

Gambar 10 : Aliran fluida dan kontrol Servovalve

Servo-valve memiliki kemampuan untuk mengontrol besaranya flow-rate yang dialirkan dengan cara mengatur signal input yang diberikan dengan persamaan $\mathrm{C}_{\mathrm{i}} / \mathrm{Nom}_{\mathrm{c}}=\mathrm{R}_{\mathrm{i}} / \mathrm{Nom}_{\mathrm{r}}$. Servovalve juga mengatur mengarahkan aliran ke port $\mathrm{A}$ atau port $\mathrm{B}$.

Untuk mendapatkan data input signal dan output flow rate pada port $A$ maupun port B diperlukan perekaman data. Data input signal direkam sebagai input value $\mathrm{C}$, output flow-rate $\mathrm{A}$ direkam melalui flow-meter A, flow-ratedisplay $A$, analog to digital kanal 0 , output value $A$, dan output flow-rate $B$ direkam melalui flow-meter $\mathrm{B}$, flow-ratedisplay $\mathrm{B}$, analog to digital (ADC) kanal 1 , output value $B$.

Untuk menentukan kinerja servovalve maka perlu dilakukan langkahlangkah pengujian servo-valve.
Langkah tersebut meliputi penyediaan peralatan uji kinerja servovalve, menyediakan benda uji berupa servo-valve, melakukan pengukuran pada pengujian statis, melakukan pengukuran pada pengujian dinamis, melakukan pengolahan data statis menjadi report, melakukan pengolahan data dinamis menjadi report, dan selanjutnya melakukan analisa terhadap report-report tersebut.

Dari reporting yang dihasilkan pada pengujian kinerja servo-valve yakni laporan pengujian statis seperti Gambar 8 berikut tambahan analisanya, dan laporan pengujian dinamis seperti Gambar 9, maka akan memberikan gambaran kinerja dari suatu servovalve, antara lain keakurasian, hysteresis, kebocoran servo-valve.

Dari grafik yang ditampilkan juga ada kemungkinan kejadian hysteresis itu yang merupakan perilaku atau sifat dari sebuah sistem dimana sebuah sistem tersebut gagal untuk kembali ke keadaan semula atau sebelumnya. Hal ini akan menjadi informasi untuk dianalisa lebih lanjut penyebabnya.

Untuk menjamin keakurasian pengukuran flow-rate oleh flow-meter, maka secara periodik perlu dilakukan kalibrasi ulang baik untuk flow-meter $\mathrm{A}$ maupun flow-meter $\mathrm{B}$.

\subsection{Sumber daya manusia dan sumber daya fasilitas}

Konsep desain alat uji servo-valve yang telah diuraikan diatas perlu direalisasikan dengan melakukan pengembangan dan rancangbangun sesuai dengan rancangan yang telah dibuat meliputi rancangan sistem hidrolik, rancangan input signal, rancangan output signal, dan rancangan pengolahan data dan reporting.

Pengembangan dan rancang bangun alat uji servo-valve ini membutuhkan kemampuan sumber daya manusia untuk melaksanakannya. 
B2TKS sebagai institusi yang telah lama berkecimpung di bidang kekuatan struktur memiliki pengalaman yang panjang dalam pengelolaan sistem hidrolik, sistem kontrol dan sistem berbasis komputer. Maka dari itu kemampuan sumber daya manusianya dapat diandalkan. Disamping itu B2TKS sudah memiliki mesin serupa.

Sumber daya fasilitas sebagian besar telah tersedia dan dapat dipergunakan segera, hanya perlu ada pengadaan beberapa komponen yang diperlukan. Ketersediaan sumber daya manusia yang mumpuni dan ketersediaan sumber daya fasilitas yang siap digunakan sudah cukup untuk segera melakukan pengembangan dan rancangbangun alat uji kinerja servovalve.

\section{KESIMPULAN}

Servo-valve adalah suatu valve yang berfungsi mengontrol aliran fluida yang masuk dan keluar servo-valve. Servo-valve memiliki pintu masuk $P$ dan pintu keluar R, A dan B. Pada servovalve terdapat instrumen elektronik yang mengendalikan arah dan volume aliran. Input signal elektrik mengakibatkan terjadi pengendalian aliran fluida.

Konsep desain alat uji kinerja servo-valve terdiri atas konsep desain mekanis dan konsep desain elektronik. Konsep desain mekanis meliputi hydraulic power pack yang dilengkapi pengaman dan monitor tekanan dan flow-rate, servo valve dan base platenya, flow-meter untuk monitor aliran di A dan B. Konsep desain elektronik meliputi pembangkit signal input kepada servo-valve, signal output dari flowmeter A dan B, akuisisi signal output flow-meter, hardware dan software komputer.

Perekaman data signal input dan data signal output secara step-by-step dapat diolah lebih lanjut menjadi informasi kinerja servo-valve antara lain analisa akurasi, analisa akurasi ratarata, dan analisa persamaan linear.
Grafik Signal Input (mAmpere) versus Signal Output (LPM) dapat membantu analisa untuk mengetahui keakurasian servo-valve dan mendeteksi kerusakan servo-valve untuk selanjutnya dapat diambil tindakan pemeliharaan dan perbaikan

Pengembangan dan rancangbangun alat uji kinerja servovalve secara nyata dapat dilakukan mengingat ketersediaan sumber daya manusia yang mumpuni dan ketersediaan sumber daya fasilitas yang cukup dan siap digunakan.

\section{DAFTAR PUSTAKA}

1. MOOG GmbH, "Servo-valve with Mechanical Feedback D761 Series", Boblingen-Germany, 2014

2. MOOG Industrial Controls Division, "G040-119 Servovalve Tester", USA, 2014

3. MOOG Australia Pty. Ltd, "Application Notes Valve Checker M040-120-001", Australia, 2014

4. MOOG Inc., Industrial Controls, "Servovalves and ServoProportional Valves Product Line Overview", USA, 2013

5. Carl Schenck AG, "General Handling Of Hydraulic System", Darmstadt-Germany, 1986

6. Carl Schenck AG, "Machine of Performance Test Of Servo-valve", Darmstadt-Germany, 1986

7. STAUFF, "One-D-Diagtronics Catalog", 2014

8. Advantech Co., Ltd., "Data Acquisition (DAQ) and Control Product", USA, 2014.

9. Delta Computer Systems, Inc., "Two Axis Voltage-to-Current Converter" Vancouver, 2014.

10. Microsoft Press, "Visual Basic 6.0 Controls Reference”, USA, 2004. 